\title{
DEMOCRACY AND PRIMARY EDUCATION SPENDING IN SPAIN 1902-22
}

Paola Azar

Sergio Espuelas 
Title: Democracy and primary education spending in Spain, 1902-22

Abstract: By the turn of the 20th century, nation-building reformers in Spain tried to stimulate schooling expansion to improve (or at least dignify) Spain's position in the international arena. However, in this paper we find that democratic imperfections help explaining the modest spread of primary schooling after the 1902 reforms. Regression results show that the lack of effective electoral competition and political patronage lowered public primary education spending across Spanish provinces in 1902-22. Voter turnout had a positive impact but it was not big enough to compensate for this negative effect.

JEL Codes: D72, H52, I28, N33, N34

Keywords: Education, Spain, Democracy, distributive politics

\section{Authors:}

Paola Azar

Sergio Espuelas

University of the Republic, Uruguay Universitat de Barcelona

Email: pazar@iecon.ccee.edu.uyＥmail: sergio.espuelas@ub.edu

Date: March 2021

Acknowledgements: We thank the participants at the VII Jornadas Uruguayas de Historia Económica and Alfonso Herranz, Nektarios Aslanidis, Xabier García, Marc Prat and Javier San Julián for their helpful comments. We also thank Marc Rivas and Alejandro Cichevski for their valuable assistance with the data. Usual disclaimers apply. Funding from the research project PGC2018-095821-B-I00 (MINECO/FEDER, EU) is acknowledged. 


\section{Introduction}

Many interpretations concerning the rise of mass primary schooling in Europe highlight the role of top-down reforms associated with nation-building efforts (Melton, 1988; Green, 1990; Ramirez and Boli, 1987). The French Ferry laws of 1880s and the 19th-century German leadership in primary education are prime examples of this phenomenon. Indeed, Paglayan (2020) suggested that democracy played a minor role in the early expansion of primary education. She argued that non-democratic regimes promoted schooling for several reasons, such as to foster industrialization, increase military strength, forge national identity and promote political loyalty. As a result, in many countries, "a majority of the population already had access to primary schooling before democratizing" (p. 17). Other authors, by contrast, have suggested that democracy played a key role in primary education expansion (Mariscal and Sokoloff, 2000; Go and Lindert, 2010; Engerman et al., 2009).

In fact, Lindert (2004) considered that to explain some of the paradoxes in the history of education concerning the effect of democracy, top-down reform theories need to be qualified and supplemented with careful analysis of the role of (de)centralization and the actual distribution of political voice. For example, according to this author, the progress of primary education in 19th-century Prussia was the result not of the imperial government, but of a decentralized system, which granted rapidly urbanizing territories enough political voice to make generous investments in education (Lindert, 2004). A similar logic could be applied to formally democratic countries. Specific aspects related to the organization of the educational system or to political dynamics could affect the actual distribution of political voice and reduce politicians' incentives to invest in education. Specifically, this paper discusses the potential impact of imperfections in political markets on the spread of schooling by examining the allocation of primary education spending across Spanish provinces in 1902-22.

The Spanish case is interesting for several reasons. First, like other European countries, Spain launched a top-down education reform shortly after the turn of the 20th century. During the Cuban War of Independence in 1898, Spain suffered a resounding defeat at the hands of the United States. As a result of this Desastre del 98, the desire for reform and to put an end to Spain's degeneration and backwardness increased and a new political and intellectual movement, Regenerationism (Regeneracionismo), emerged. Many blamed the defeat on ignorance. Santiago Alba, Minister of Education in 1912 and 1918, said in 1901 that it was not the US soldiers but "the Yankee school, rational, human, [and] flourishing (...) that defeated the Spanish school, primitive, routine, [and] poor" (cited in Villares and Moreno Luzón, 2009, p. 328). As in France after the Franco-Prussian war of 1870, the military defeat paved the way for education reform. Thus, in 1900, the government created the Ministry of Education and, in 1902, took over payment of primary school teachers' salaries and the purchase of school supplies. These measures were inspired largely by the French Ferry laws of 1880s, but the Spanish results were much poorer. Literacy rates increased gradually, but even in $1920,39 \%$ of the population was illiterate and major regional differences persisted.

Secondly, the Spanish education reforms were implemented under a semi-democratic regime. During the Bourbon Restoration (1874-1923), Spain was officially a democracy. However, electoral fraud, corruption and widespread political patronage enabled the 
political elite to largely ignore bottom-up demands. The system was dominated by two main parties, the Conservatives and the Liberals, which had agreed to alternate in power by means of rigged elections. Before each election, the two ruling parties planned a provisional electoral result in which the incoming party always obtained a majority in Parliament. This national agreement was then implemented by local elites in their districts through widespread client-patron relationships, or by means of massive vote buying and outright intimidation.

Local elites, in fact, played a crucial role in this system. They acted as intermediaries between the public resources offered by national members of parliament (MPs) to buy electoral support and local communities or individuals. This gave local elites a great deal of power, and national MPs often had to negotiate with them to ensure that the prearranged electoral results were successfully implemented (Moreno-Luzón, 2007).

Despite its corrupt nature, this system allowed for some political stability, but it weakened over time. In urban areas in particular, elections became increasingly competitive and the candidates of the dynastic parties (Conservatives and Liberals) gradually lost ground in favor of those from emerging parties. Additionally, since the two ruling parties found it more difficult to control the electoral results, and thus ensure that their candidates were elected, political patronage and the influence of local elites in national politics increased. Some national MPs decided to reinforce their clientelist ties with local elites to ensure that they were elected (or re-elected), and the so-called candidatos propios (candidates who were repeatedly elected in the same electoral district outside of the alternation system) gradually increased.

To analyze the impact of these political factors on primary education spending, we used a historical dataset that included both electoral outcomes and the distribution of central government education spending across Spanish provinces in 1902-1922. The period comprises the years between the 1902 education reform and the coup d'état led by Primo de Rivera in 1923, which put an end to the Bourbon Restoration. The empirical approach exploits the variation in the share of candidates from emerging parties and the share of propios across Spanish provinces and over time to evaluate the impact of the electoral competition (or lack thereof), political patronage and voter turnout.

Our results reveal the following. First, the national government lowered primary education investment in provinces with a high share of elected candidates from non-dynastic parties. However, this effect was non-linear. In more industrialized areas and in provinces where the share of candidates from emerging parties was particularly high, the government did in fact increase education spending. In line with Curto et al. (2012), we interpreted this as the result of the regime's strategy to achieve political stability. The ruling duopoly initially punished the opposition provinces as a way of enforcing the alternation system, but later, when opposition increased, the government tried to appeal to these provinces for the sake of political stability. This is consistent with the expected behavior of a semi-democratic regime (Robinson and Torvik, 2009). Second, the share of propios had a negative effect on education spending, thus suggesting that political clientelism hindered education expansion in Spain. This is consistent with theories predicting that clientelist policies lead to the underprovision of non-targeted goods (e.g., universal primary education) and the overprovision of targeted goods (e.g., public jobs and public works projects) (Keefer, 2007). 
Third, voter turnout had a positive effect, but it was not enough to compensate for the negative influence of political patronage and the lack of political competition.

Shortly after the turn of the century, nation-building reformers in Spain attempted to stimulate schooling expansion to improve, or at least dignify, Spain's position in the international arena. However, we show that democratic imperfections, primarily the lack of effective political competition and widespread political clientelism, can explain the modest spread of primary schooling after the 1902 reforms. This means that the arguments posed by Paglayan (2020) may explain the timing of the reform. But, as Lindert (2004) indicates, to understand the final outcome of the reform it is necessary to take into account the role of political voice and democracy.

These findings, therefore, contribute to existing debates on the role of democracy in the early expansion of primary education. Moreover, instead of focusing on non-democratic regimes with rapid educational expansion (such as Prussia), our paper focuses on a semidemocratic regime with poorer educational outcomes to analyze the impact of democratic shortcomings on education expansion. Our paper is also the first to analyze the influence of political dynamics on public primary education spending during the Restoration in Spain. Previous studies have typically focused on economic or institutional factors, such as land inequality and access to common land (Beltrán Tapia and Martínez-Galarraga, 2018; Beltrán-Tapia, 2013) or have been more descriptive in nature (Beltrán-Tapia et al., 2019; Núñez, 1992; Pérez Moreda, 1997). In that respect, the democratic shortcomings that we identify may also have implications for the debates around the slow economic growth that took place during the Restoration (O'Rourke and Williamson, 1997; Prados de la Escosura and Rosés, 2010).

The paper is organized as follows. The next section summarizes the theoretical framework; Section 3 describes the educational system and political setting of early 20th-century Spain; Section 4 presents the data and methodological approach; Section 5 outlines the results of the econometric analysis; and, lastly, Section 6 offers a conclusion.

\section{The rise of primary schooling: potential explanations}

There is currently no consensus on the relationship between democracy and education. Several studies have emphasized the importance of democracy and the extension of voting rights to generate broad demand for schooling expansion (Mariscal and Sokoloff, 2000; Go and Lindert, 2010; Engerman et al., 2009). However, other accounts on the rise of modern education have focused on the role of top-down reforms implemented by political elites for nation-building purposes (Melton, 1988; Green, 1990; Ramirez and Boli, 1987). Paglayan (2020) suggested that non-democratic regimes may show an interest in schooling expansion to foster industrialization, increase military strength, forge national identity or promote political loyalty. This would, in turn, explain why primary school expansion has often preceded the full consolidation of democracy.

To explain the apparent discord between scholars who associate schooling spread with either top-down reforms or democracy, Lindert (2004) stated that the discussion needs to go hand in hand with a reassessment of the role of (de)centralization. In non-democratic 
Prussia, for example, decentralization granted political voice to rapidly urbanizing regions with a high demand for education. This made it possible to quickly expand primary schooling (in this areas) and overcome the opposition of Junker-dominated areas. ${ }^{1}$ Conversely, in countries like France and, above all, Italy, where regions with a low demand for education or poor fiscal capacity were in the majority, decentralization led to poorer schooling outcomes. The extension of voting rights in this context had a modest positive effect. It was centralization, together with existing voting rights, that ultimately gave rise to schooling expansion (Lindert, 2004; Cappelli, 2016a, 2016b; Cappelli and Vasta, 2020). Chaudhary et al. (2012) also showed that decentralization and the lack of broad political voice in developing countries, particularly Brazil, Russia, India and China, led local elites to capture political institutions and delay the expansion of primary education.

More generally, the attitude of powerful local lobbies towards mass schooling has been the subject of widespread discussion. Recent empirical analyses have suggested that political elites, particularly landed elites, boosted the expansion of education in the 19th century in Sweden and Austria (Andersson and Berger, 2019; Cvrcek and Zajicek, 2019). Other studies, however, are less optimistic about the effect of strong landed elites. Cinnirella and Hornung (2016) and Beltrán Tapia and Martínez-Galarraga (2018), for example, considered that land inequality negatively affected the demand for education. Galor et al. (2009) and Goñi (2018) also found a negative correlation between land inequality and schooling, but highlighted the role of supply-side factors, namely the opposition of landed elites to education reforms.

Other studies have analyzed the relationship between democracy and the provision of public goods, but have focused on the influence of political motivations rather than centralization or special interests. Keefer and Khemani (2005) and Keefer (2007) showed that governments that rely on clientelist practices tend to overprovide targeted goods (such as public works projects and public jobs) to narrow groups of voters and to underprovide non-targeted goods (such as universal healthcare and education). This is because patrons have weak incentives to provide general public goods to benefit clients and non-clients alike. It is interesting to note in that respect that Curto et al. (2012) found that clientelist politics played a crucial role in road investment allocations in Spain in 1880-1914.

Keefer and Khemani (2005) also accounted for the importance of electoral party competition for the provision of public goods. In the absence of credible opposition parties, the incumbent party can win elections with exceedingly modest promises. Competition, by contrast, may lead to the higher provision of public goods and a reduction in political patronage if the competing political parties are able to make credible promises to broad segments of the population in search of electoral support. The authors supported their claims with evidence from contemporary India. However, there is also historical evidence that points in the same direction. Eli and Salisbury (2016), for example, found that the expansion of pensions for Confederate veterans and widows in the southern United States during the 1920s occurred in counties where Democratic candidates were threatened by alternative parties in elections.

The discussion on political motivations to allocate public goods is related to the field of distributive politics or "pork barrel" models. Based on the original contributions by Cox and

\footnotetext{
${ }^{1}$ In the US, decentralization also allowed regions with high demand for education to rapidly expand schooling
} in the 19th century (Goldin and Katz, 2008; Go and Lindert, 2010). 
McCubbins (1986) and Lindbeck and Weibull (1987), a wide range of studies have discussed whether politicians target public goods towards their core constituencies or those with a majority of swing voters (Dixit and Londregan, 1996). Political parties can target their core voters to mobilize their electoral base and minimize the loss of voters who have weak partisan attachments (Cox, 2010). On the other hand, they can address voters whose future support is uncertain, i.e., voters who are ideologically weakly opposed to the relevant party (Stokes, 2005). Most of these studies analyze infrastructure and local transfers worldwide. ${ }^{2}$

Along similar lines, the distribution of public funds might well reflect the influence of individual MPs, who seek to reinforce their electorate support. In this case, benefits could flow to relevant figures whose support may be crucial in overcoming majority requirements in the legislative process (Cox, 2009).

The core and swing voter hypotheses have been developed for democratic contexts, in which political parties have to compete for the support of the electorate. Nonetheless, Robinson and Torvik (2009) expanded this general framework to semi-democratic contexts in which standard democratic strategies to gather political support, such as public goods provision and redistribution to potential voters, are combined with coercion and violence. In these political contexts, swing voters are able to attract more public resources and generate more public goods provision only when the government is unable or unwilling to successfully implement coercive methods. Again, Curto et al. (2012) found that in Restoration Spain the government used road investment allocations to punish provinces that elected candidates outside the alternation system. However, during the last few years of the 19th century, when political and social mobilization increased, this strategy was abandoned and "swing" (or rebel) provinces were in fact favored for the sake of political stability.

Our contribution to this debate was to study whether the strategies developed by politicians to hold electoral support conditioned the spread of schooling under the centralized system implemented by the Restoration regime in Spain at the turn of the 20th century. To our knowledge, few studies have analyzed the disruptive influence of politics on the expansion of education. In Azar (forthcoming) the effect of political tactics on school provision is documented for Uruguay during the first half of the 20th century. Another case -albeit not entirely analogous- is the study conducted by Cinnirella and Schueler (2018), who found that the vote share of pro-nationalist parties was boosted by the increase in primary education spending in Imperial Germany.

\section{Historical background}

\subsection{The education system}

Spain's first national education law, the so-called Moyano Law, was passed in 1857. It was inspired largely by the French Guizot Law of 1833. Education was divided into primary, secondary and university levels. A clear distinction between public schools (funded with public resources) and private schools (funded by private individuals or institutions) was established. Schooling was declared compulsory for children between the ages of six and nine and was free of charge for poor families. To benefit from free schooling, a certificate

\footnotetext{
2 For a survey on the literature on distributive politics, see Golden and Min (2013).
} 
issued by the local authorities was required. The definition of "poor," however, seems to have been quite broad, as schooling was free for more than half of children by 1860 .

The new legislation required local governments to set up a minimum number of schools, depending on population size (Núñez, 1991, 1992). ${ }^{3}$ Primary enrollment rates increased gradually from 1860 but progress was rather slow: percentages were $36 \%$ in 1860, 47\% in 1878 and even in 1900, they were below 45\% and a far cry from European standards (Núñez, 1992, p. 294).4 Moreover, this rather modest increase in literacy occurred mainly in areas that already had relatively high literacy rates, such that preexisting regional disparities in literacy rates actually increased under the Moyano Law (Beltrán-Tapia et al., 2019). A snapshot of literacy rates across Spanish provinces in 1900 (Map 1) shows a clear divide between the northern half of the country, which had above-average literacy rates (with the exception of Galicia in the northwestern corner), and the Mediterranean coast, especially the southern provinces, which presented lower rates.

\section{[Map 1 here ]}

The Moyano Law established nationwide regulations, but funding remained a local responsibility. As a result, schooling expansion was concentrated in areas where local governments were able (or willing) to raise enough taxes to fund primary education. In this regard, Beltrán-Tapia (2013) showed that the persistence of common land, which contributed to both municipal and household income, led to higher levels of education spending. It is also likely that the average size of the local population conditioned school provision because of the way the law was designed. Since the Moyano Law required that least one school be created in the smallest municipalities, school provision increased in areas where small towns were predominant, such as north-central Spain (Pérez Moreda, 1997). Local demand for schooling should also have been shaped by the economic activities typical of each region. Thus, one would expect that traditional agricultural areas were less interested in developing mass schooling than industrialized, urban and commercial regions (Núñez, 1992; Pérez Moreda, 1997).

As mentioned in the introduction, the Desastre del 98 paved the way for education reform. For many, education became the key to economic progress and political and social regeneration. As expressed by writer Emilia Pardo Bazán in 1901, “Our problem is a problem of education and culture"; this was a widespread opinion among both the general public and the policymakers of the Restoration regime. Until then, schooling debates had focused mainly on ideological issues related to academic freedom and secularization (Villares and Moreno Luzón, 2009; Otero, 2018).

After the Desastre, the liberals embraced the program reform devised by the Institución Libre de Enseñanza. This was an influential institution established in 1876 that advocated

\footnotetext{
${ }^{3}$ Municipalities with fewer than 500 inhabitants were required to maintain at least one incomplete school. Municipalities with more than 500 inhabitants had to maintain at least one complete school for boys and one incomplete school for girls. Municipalities with more than 2,000 inhabitants had to maintain two complete schools for boys and two for girls, a proportion that would be progressively expanded. Complete schools had to be run by teachers with a formal academic degree, whereas incomplete schools could be run by "any person of legal age, able to read and write, and of good manners," requirements often fulfilled by the parish priest (Núñez, 1992, p. 256).

${ }^{4}$ As early as 1870 , several European countries (Denmark, France, Germany, the Netherlands, Sweden and the UK) had literacy rates of between $70 \%$ and $80 \%$ of the adult population (Crafts, 1997).
} 
for urgent reforms to change the organization, methods and curricula of the school system and move towards secularization. Some factions of the Conservative Party also committed to similar reforms, such that, rather than being a fight between the Liberal and Conservative parties, the battle over schooling turned into a dispute between reform supporters from both ideologies and Catholics groups (Moreno Luzón, 2001). At the turn of the century, the government created the Ministry of Education (Ministerio de Instrucción Pública y Bellas Artes). One year later, in 1901, the upper age for compulsory schooling was extended from nine to 12 years. In 1902, the national government took over payment of primary school teachers' salaries and the purchase of school supplies, in line with the example set by the French Ferry laws. The construction and maintenance of schools, however, remained the responsibility of local governments.

Average primary education spending per capita across Spanish provinces increased by almost 70\% between 1902 and 1922 (from 1.72 to 2.91 constant pesetas). Literacy rates increased more gradually (Table 1). The modernization of the Spanish economy probably contributed to this process, as urbanization generated greater demand for education. However, progress was rather slow and remained a far cry from European standards. In 1920 , the Spanish literacy rate among the adult population was $61.1 \%$, while the literacy rate in countries such as the UK, the Netherlands, Germany and Sweden had already exceeded $80 \%$ by 1870 . Moreover, Table 1 shows that these poor results were accompanied by a huge gender gap (Beltrán-Tapia et al., 2019).

Table 1. Literacy rates in Spain, 1860-1920 (\%)

\begin{tabular}{cccc}
\hline Year & Male & Female & Total \\
\hline \hline 1860 & 41.7 & 11.9 & 26.5 \\
1877 & 46.7 & 19.3 & 32.5 \\
1887 & 52.1 & 24.9 & 38.1 \\
1900 & 57.1 & 33.3 & 44.8 \\
1910 & 62.9 & 42.3 & 52.2 \\
1920 & 70.1 & 52.9 & 61.1 \\
\hline
\end{tabular}

Source: Beltrán-Tapia et al. (2019)

Regional disparities also persisted after centralization. Map 2 shows the Spanish literacy rates in 1920. Even if there was some convergence in the cases of Galicia and Barcelona, for example, there was still a clear divide between the northern provinces (with high literacy rates) and the southern provinces and Mediterranean coast (with low literacy rates). Apparently, this situation persisted until the Second Republic (1931-36), when the government launched an ambitious primary education policy that reduced the existing imbalances (Núñez, 1991).

\section{[Map 2 here]}

A look at the distribution of central government expenditure per capita on primary education across Spanish provinces between 1905 and 1920 shows the same regional split observed in the case of literacy (Map 3). Despite the average increase in primary education spending, the northern half of the country (except for Galicia) showed higher levels of education spending than the Mediterranean coast and southern regions. It seems, therefore, that the centralization process initiated in 1902 did not lead to regional convergence in terms of the allocation of schooling resources. The north-south divide persisted and there 
was even some homogenization among southern provinces at low spending levels. The objective of this paper is to analyze whether political factors can help explain the limited impact of the 1902 reforms. Before doing so, it is important to summarize the main features of the Spanish political system at the time.

\section{[Map 3 here]}

\subsection{Political context}

In 1874, a parliamentary monarchy under the Bourbon dynasty was established in Spain and led to the so-called Restoration period (1874-1923). In the preceding decades, particularly since the start of Isabella II's reign in 1833, military coups, or pronunciamientos, had been common. Since massive electoral fraud prevented any political alternation in government, political leaders in the opposition often relied on the military to organize plots to overthrow the government (Sabaté et al., forthcoming).

During the Restoration period, the two main parties (the Conservatives and Liberals), or "dynastic parties", agreed to alternate in power by means of fraudulent elections, the socalled turno pacífico ("peaceful turn"). The role of the Crown was to give the system support and stability. Anti-liberal sectors of the Catholic right and groups of leftist republicans and revolutionaries were excluded from the alternation system. This design created some political stability, but it came at the price of widespread corruption and limited political competition. It worked as follows. Before each election, the incoming and incumbent parties came together to plan the preliminary distribution of the chamber seats, which always gave the former the victory. This national agreement, or encasillado, had to be implemented by the local elites on election day.

Several mechanisms were used to enforce the encasillado. Massive vote buying was common practice and increased substantially after the introduction of universal male suffrage in 1890. Fraudulent activities, such as manipulation of the electoral census, and outright intimidation, which was particularly effective in areas where the labor market was close to monopsony, were also frequent. However, the main source of political control arose from widespread political patronage. Local bosses, or caciques, were crucial to this end. They acted as intermediaries between national MPs and their local communities by providing their clients with access to public resources. Given the nature of the Restoration system, national leaders often had to negotiate with local elites to implement the prearranged electoral results. In turn, these close ties with national leaders increased the political influence of local bosses.

The political power of the caciques lay more in their control over administrative mechanisms than in their privileged economic position, although the two factors were often linked (Comín, 1988; Moreno-Luzón, 2007). Their social profile varied from region to region. Landowners, for example, were predominant in the south and west (Andalusia, Extremadura and parts of Castile). Mid-sized farmers were common in Valencia, in the east. Professionals, particularly lawyers, who had good knowledge of the administrative system, played a leading role in regions such as Catalonia and Galicia. Finally, merchants and shipowners were very active in Valencia, Seville and Cadiz, and industrialists were predominant in Catalonia (Moreno-Luzón, 2007). 
From the beginning of the Restoration period, the local elites in some electoral districts established long-term relationships with their corresponding MPs to ensure that they were elected or re-elected without respecting the electoral turn. These MPs were known as propios, as they were said to "own" an electoral district and were continually elected independently of their party affiliation (Moreno-Luzón, 2007). This behavior was initially more common where propios proved to be particularly effective in obtaining resources for the elites' clientele. This increased their chances of being re-elected and boosted the influence of local elites in national politics.

This governing scheme operated rather successfully until the end of the 19th century. However, social unrest at the turn of the 20th century expedited the demand for political change. In 1907, the Conservative government implemented an electoral reform. Voting was declared compulsory, with sanctions devised for civil servants who did not vote, although this was rarely enforced. To prevent fraud and manipulation, mayors were removed from polling stations, the Supreme Court was made responsible for checking the electoral results and independent electoral boards were created.

Additionally, Article 29 established that no elections would take place in districts with only one candidate, who would automatically win the election. This peculiar electoral rule, initially conceived to stimulate political participation, had the opposite effect and led to the election of more than a quarter of the total number of MPs elected between 1910 and 1923. In any case, the 1907 reform did not introduce greater proportionality, which would have benefited emerging parties, and electoral districts remained very small, which benefited the local bosses and led to the persistence of clientelist practices.

In addition to these subtle changes, a number of historical events fueled the emergence of deep-rooted political and social conflicts. The Restoration system weakened over time due to both external factors (namely, the emergence of new parties, especially in urban areas) and internal factors (the gradual strengthening of the local elites) (Villares and Moreno Luzón, 2009).

According to Comín (1988), the abovementioned national identity crisis provoked by the Desastre del 98 represented a major turning point in the Restoration period. However, the Tragic Week of 1909, which plunged Barcelona into violent anticlerical riots, and the discrepancies over Spain's neutrality during the First World War, which led to additional ruptures between pro-Allies and pro-German factions, were also key events. In 1917, in the midst of the armed conflict, growing military discontent over poor pay conditions caused a government crisis. This, alongside increased political mobilization by leftist republicans and Catalan nationalists and the labor movement, led to the worst crisis faced by the Restoration regime since its creation (Villares and Moreno Luzón, 2009).

From 1918 onwards, the government found it increasingly difficult to obtain a parliamentary majority. Legislative representatives were renewed every year in 1918, 1919 and 1920, respectively, as opposed to the two-year terms that had been the general rule in previous years. In fact, after the introduction of universal male suffrage in 1890, the average voter turnout across provinces ranged from $68 \%$ to $74 \%$ and voters slowly began to be persuaded by the ideological arguments of minority parties like the republicans, the Catalan 
nationalists and the socialists, who won parliamentary representation for the first time in 1910.

In this context of increasingly competitive elections, minority parties gained more influence and, more importantly, encouraged modern political behavior. ${ }^{5}$ As Moreno-Luzón (2007) put it, the rise of these parties meant "the arrival of the masses in the political arena" (p. 431). Especially after the First World War, the traditional methods that were predominant in rural areas coexisted alongside the modern political behavior seen mostly in industrial cities, although fraud and political patronage remained widespread until the collapse of the Restoration regime in 1923. Figure 1 shows how the share of MPs of dynastic parties remaining in the opposition increased after 1907, thus reflecting the difficulties associated with reaching a consensus on the distribution of MPs. By the end of the period, over $45 \%$ of MPs belonged to the dynastic opposition or to minority parties.

\section{[Figure 1 here ]}

After the increasing politicization in cities, the main factor behind the deterioration of the Restoration system was the gradual strengthening of local elites. With the crisis of the dynastic parties, a growing number of MPs looked for the protection of local powers "...in order not to be swept away by the instability of the government" (Moreno-Luzón, 2007: 435). This led to an increase in the share of propios in Parliament (who, as previously mentioned, were continually elected independently of their party affiliation, without respecting the electoral turn). Our computations show that they grew from $40 \%$ in 1901 to 49\% in 1922 and 57\% in 1919. This compounded the difficulties of the post-First World War political instability and reflected the deterioration of the Restoration system until it was finally overthrown by the military coup led by Primo de Rivera in 1923.6 Map A-1 in the Appendix shows that propios were distributed throughout the territory. Their presence, associated with different types of local bosses, or caciques, was common in most provinces during the period.

\section{Empirical approach}

To analyze the influence of the Spanish semi-democratic regime on primary schooling investment following the 1902 reforms, we exploit changes in political factors resulting from the gradual breakdown of the Spanish Restoration system. In particular, we consider: i) changes in electoral competition and ii) changes in the spread of political clientelism across provinces and over time. Changes in electoral competition are approximated by the variation in the political representation of opposition parties, which is an indication of the government's ability to implement the prearranged electoral results and therefore limit electoral competition. To examine the impact of political clientelism, we focus on differences in the share of propios at the local level. Remember that these were MPs who established particularly stable patron-client relationships with local bosses. Our starting hypothesis is that the lack of electoral competition and widespread political clientelism lowered the

\footnotetext{
${ }^{5}$ Basque nationalists, Carlists and traditionalists also became politically relevant in the Basque Country and Navarre. However, as shown in the following sections, our analysis excludes these provinces because of a lack of data.

${ }^{6}$ See Section 4 for more details on the precise definition used in the calculations.
} 
central government's spending on primary education at the local level. The basic model to be estimated is as follows:

$Y_{i t}=\beta P_{i t}+\gamma X_{i t}+\alpha_{i}+\lambda_{t}+\mu_{i t}$

where $Y_{i t}$ stands for the central government's spending on primary education in province (i) and year $(t)$; $P_{i t}$ includes our political variables; $X_{i t}$ stands for a set of control variables; $\alpha_{i}$ are province fixed effects; $\lambda_{t}$ are time fixed effects and $\mu_{i t}$ is an error term.

In the specifications, we assumed that central government spending on education in one given year was influenced by the current legislature and, therefore, by the results of the nearest previous election. Consequently, the value of the political variables is the same within each legislative term. Fixed effects at the province level control for unobserved local characteristics that are constant over time, such as geographic, institutional and cultural features. Therefore, we identify the effect of political variables through within-province variation over time instead of between-province sectional variation. Likewise, year fixed effects capture unobserved external changes over time that affect all provinces, such as national budget constraints or extensions that are decided centrally. The potential nonindependence of errors within departments are tackled by clustering standard errors at the province level.

Data on the provincial distribution of central government spending on primary education were obtained from the Spanish general state budgets (Presupuestos Generales del Estado and Cuentas Generales del Estado), which indicate the outlays by province on both personnel and material (personnel accounted for 89\% of the total). ${ }^{7}$ From 1917 onwards, however, the general state budgets offer aggregated figures for Spain only as a whole. In this case, the information was obtained from Spain's statistical yearbooks, which also include information on central government outlays on primary education disaggregated at the province level for those years. Where there was a discrepancy between the total amount reported in the Spanish general state budgets and the statistical yearbooks, we retained the total figure reported in the budgets and the same distribution across provinces reported in the statistical yearbooks. Data for 1921 were missing and were therefore interpolated. The Basque Country and Navarre were excluded from the analysis, as their education expenditure was financed and executed directly at the provincial level. Our new database, therefore, consists of a total of 45 provinces. The time period starts in 1902, when the central government took over primary schooling expenditure, and ends in 1922, before the Restoration broke up. The amounts are expressed in constant pesetas per capita at 1914 prices. The information about provincial population was taken from Roses et al. (2010) and interpolated to fill in the gaps.

As for the political factors $\left(P_{i t}\right)$, we consider a set of variables. To capture the effect of the increasing political competition for each legislative term, we classify all MPs according to their membership to one of the two dynastic parties (Liberals or Conservatives) or to any of the minority parties (e.g., left-wing republicans, right-wing traditionalists, Catalan nationalists and socialists). We then calculate the share of MPs belonging to minority parties

7 The Presupuestos Generales del Estado are passed by the government and include all budgeted expenditure. The Cuentas Generales del Estado are drafted at the end of the financial year and include all budgeted expenditure plus settled and executed expenditure. In 1918-20, the Presupuestos Generales were unavailable, so we obtained the data from the Cuentas Generales. 
and the share of MPs belonging to the dynastic opposition (e.g., the share of Liberals or Conservatives remaining in the opposition) in each province. ${ }^{8}$ During the period of analysis, the Liberals held government in 1901-1902, 1905-1906, 1910-1913 and 1916-1918. ${ }^{9}$ In the remaining years, they were the dynastic opposition party. Obviously, the opposite was true for the Conservatives. Data on the affiliation of MPs for the period 1902-1914 were obtained from Curto et al. (2012). Information for subsequent years was taken from Varela (2001), who compiled the name, district and party of all MPs. The missing data were filled in from the website of the Spanish Historical Archive of the Congress of Deputies, which also provides the name and district of all elected MPs. ${ }^{10}$

The expected sign of the share of minority and dynastic opposition MPs points in two different directions. As discussed in Section 2, one would initially expect increased political competition to have a positive impact on education spending. However, in semi-democratic contexts such as the Restoration system, coercive methods may allow governments to ignore swing voters' demands and lower redistribution in their favor (Robinson and Torvik, 2009). Thus, our starting hypothesis is that, in the election years when the ruling duopoly successfully implemented the alternation system, the emergence of new parties was detrimental to education spending. This is because the government was able to ignore voters in swing constituencies and focus on core voters. However, it is also likely that, as the regime weakened and minority parties increasingly gained ground, the government had an incentive to replace this punishment strategy with one of attraction. As mentioned before, this seems to have occurred in the case of road construction (Curto et al., 2012).

To test whether the government changed its strategy as the opposition increased, we modified our baseline equation to allow for a potential non-linear relationship between education expenditure and increasing political opposition. Thus, the analysis also included both the share of minority party MPs and the share of dynastic opposition MPs squared.

Another relevant political variable in our analysis is the presence of propios. As mentioned in previous sections, propios were MPs with close links to local bosses as a result of particularly fruitful and long-standing clientelist relationships. As in Curto et al. (2012), we defined propios as MPS who: i) had been elected in the past in the same district, ii) belonged to one of the dynastic parties and iii) had sat with the opposition for at least one term (that is, they did not conform to the alternation system). Our calculations consider the continuity of these MPs from 1901 onwards. As before, the data came from Varela (2001) and the website of the Historical Archive of the Congress of Deputies. The expected sign of this

\footnotetext{
8 It is worth noting that provinces were composed of more than one electoral district. This means that when we calculated the share of MPs belonging to each party at the province level, we in fact aggregated the information and probably smoothed potential local variation (existing at the district level). This might have led to measurement errors, but the information on education spending provided by government records is disaggregated at the province level only, thus making this aggregation unavoidable. Moreover, there are reasons to believe that this aggregation causes relatively minor problems. It seems that provinces were fairly consistent key political units in the Restoration system (Moreno-Luzón, 2007, p. 435). Before each election, for example, the Minister of the Interior used to provide the provincial governors with the list of candidates who should be elected in their districts according to the Encasillado. If provinces were indeed relevant political units to ensure the Restoration regime worked, this would help reduce the problems associated with aggregation.

9 In 1901, 1905 and 1910, the Liberals won the elections and formed stable governments that lasted for the whole term. However, after 1917, incumbent governments were often forced to resign and national governments comprising liberals and conservatives became common. In these cases, we consider the dynastic opposition party to be the party that initially lost the election.

10 See https://www.congreso.es/web/guest/historico-diputados
} 
variable is negative, as we do not expect propios to have an incentive to struggle for education resources that, unlike public works, for example, would benefit both clients and non-clients.

Our estimates also account for the relative seniority of MPs. This variable indicates the difference between the maximum seniority in the legislative term and that of each MP, measured as the number of legislative terms for which he had been elected. ${ }^{11}$ Since seniority could be the result of a leadership position in the corresponding party and could also lead to better access to information and state officials, we would initially expect more senior MPs to be in a better position to obtain public funding for their provinces. However, it is also true that in a context of widespread political patronage such as Restoration Spain, senior MPs may have had little incentive to use their presumably increased capacity to attract resources to improve schooling provision, which, as mentioned above, would benefit both clients and non-clients.

Voter turnout is also included to test whether growing political participation translated into higher primary education spending. It is computed as the ratio between the total number of votes and the potential electorate at the province level, based on the number of people on the electoral register. As already mentioned, from 1910 onwards, voting was not required in districts where only one candidate was running for election, in accordance with Article 29. Therefore, our voter turnout computations only took account of districts in which elections were actually held. We included as an additional variable the share of MPs who entered Parliament through Article 29 in each province. The information was obtained from Martínez Cuadrado (1969). Where there were information gaps or minor incongruities, the information was checked and completed with the Spanish statistical yearbooks, which also provide information disaggregated at the province level on electoral results from 1916 onwards, and the website of the Historical Archive of the Congress of Deputies. Regretfully, these data are available from 1907 onwards only. Information for 1914 and 1915 is also missing. Initially, the expected sign of this variable is positive, although fraud may have played a role in reducing the potential positive effect of electoral participation in the context of the Spanish Restoration.

Finally, we include a set of controls to capture other factors that influenced the allocation of education spending across provinces. We compute the share of school-age children between five and 15 years old over the total population and the population density (i.e., population per square $\mathrm{km}$ ) at the province level. We also include the share of older people (above 60 years old) over the total. These variables take account of the different competing interests for public funding according to the age structure and the distribution of the population throughout the territory. The information on total population, and its composition by age bracket, at the local level was retrieved from the national census (1900, 1910 and 1920) and interpolated to fill in time gaps. Data on province area were obtained from DíezMinguela et al. (2016). Adult literacy rates (lagged 10 years) were also included to control for parents' level of education and the "cultural setting." GDP per capita was used to measure the economic development of each province. We expected richer, more educated

\footnotetext{
${ }^{11}$ The variable is computed as $\frac{1}{N} \sum_{n=1} T_{t}^{\max }-T_{n, i, t}$ where $T_{t}^{\max }$ : the maximum number of times an MP had been elected until period $\mathrm{t} ; T_{n, i, t}$ : the number of times an MP $\mathrm{n}$ in province $\mathrm{i}$ in election year $\mathrm{t}$ had previously been elected. $\mathrm{N}$ : the total number of MPs at the province level in year t (Curto et al., 2012).
} 
regions to have higher education demands. GDP per capita was taken from Rosés et al. (2010) and literacy data from Núñez (1992). Finally, we use the share of the labor force employed in non-rural activities (i.e., manufacturing and services) to account for the higher demand for human capital envisaged in non-rural contexts. The idea is that skilled labor was not a prime requirement in agricultural societies but became increasingly relevant as urbanization and non-rural activities grew (Lindert, 2004). This variable was taken from Rosés et al. (2010). Table 2 summarizes the descriptive statistics for the panel.

\section{Table 2. Descriptive statistics}

\begin{tabular}{lccccc}
\hline Variable & Obs. & Mean & Std. dev. & Min. & Max. \\
\hline \hline Education exp. p. capita (1914 pesetas) & 945 & 1.79 & 0.82 & 0.38 & 6.18 \\
Share minority seats/total & 945 & 0.11 & 0.20 & 0.00 & 1.00 \\
Share dynastic opposition seats/total & 945 & 0.29 & 0.20 & 0.00 & 1.00 \\
Share propios/total & 945 & 0.44 & 0.23 & 0.00 & 1.00 \\
Relative seniority & 945 & 3.34 & 1.98 & 0.36 & 8.00 \\
Voter turnout & 617 & 0.71 & 0.09 & 0.46 & 0.87 \\
Share of MPs Art. 29/total & 945 & 0.17 & 0.25 & 0.00 & 1.00 \\
GDP/1000 p. capita (1914 pesetas) & 945 & 0.60 & 0.27 & 0.21 & 2.57 \\
Population density (pop./sq. km) & 945 & 45.83 & 29.80 & 14.69 & 184.13 \\
Adult literacy rates (lagged 10 years) & 945 & 46.56 & 16.69 & 20.18 & $104.82^{*}$ \\
School-age children over total pop. & 945 & 0.24 & 0.03 & 0.18 & 0.39 \\
Older people over total pop. & 945 & 0.08 & 0.01 & 0.04 & 0.12 \\
Share of non-rural employment (services \& & 945 & 0.30 & 0.14 & 0.07 & 0.91 \\
manufacturing) & & & & & \\
\hline \hline
\end{tabular}

Notes: *Adult literacy rates are calculated by using the population over 10 years old as a proxy for the adult population. Values above 100 suggest that some children under 10 were literate. See Núñez (1992), p. 94.

\section{Results}

Table 3 summarizes the results of the baseline specification. Columns 1 and 2 indicate the estimates of a first set of political variables, excluding voter turnout, for which the number of observations was much smaller. Column 2 includes our set of control variables. In both cases, the share of minority party seats shows a negative and significant effect. It seems that the government was able to ignore the demands of less loyal constituencies and to focus on the more loyal ones, a finding consistent with the expected behavior of a semi-democratic regime such as the Spanish Restoration. Moreover, as stated in Curto et al. (2012), it is likely that the government implemented this punishment strategy to give opposition constituencies an incentive to join the alternation system.

The share of propios also shows a negative and statistically significant effect. That is, primary education outlays were lower in provinces where clientelism was more widespread and MPs had closer ties to local bosses. This suggests that propios had little incentive to pressure for primary education spending that would benefit both their clients and non-clients. Interestingly, in their study on road spending, also during the Spanish Restoration, Curto et al. (2012) found that propios had a strong positive effect on road investment, which, unlike education, could be targeted to specific groups much more easily. 
Table 3. Political determinants of primary public education expenditure

\begin{tabular}{|c|c|c|c|c|}
\hline \multirow[t]{2}{*}{ Dependent variable } & \multicolumn{4}{|c|}{ Primary education exp. per capita (constant pesetas) } \\
\hline & $(1)$ & $(2)$ & (3) & (4) \\
\hline \multirow[t]{2}{*}{ Share minority seats } & $-0.526^{* * *}$ & $-0.445^{* * *}$ & $-0.569 * *$ & $-0.511^{* *}$ \\
\hline & $(0.174)$ & $(0.148)$ & $(0.212)$ & $(0.184)$ \\
\hline \multirow[t]{2}{*}{ Share propios } & $-0.458 * * *$ & $-0.293^{* * *}$ & $-0.572^{* * *}$ & $-0.439 * * *$ \\
\hline & $(0.132)$ & $(0.104)$ & $(0.176)$ & $(0.135)$ \\
\hline \multirow[t]{2}{*}{ Share dynastic opposition seats } & -0.003 & 0.004 & -0.019 & -0.007 \\
\hline & $(0.064)$ & $(0.057)$ & $(0.119)$ & $(0.109)$ \\
\hline \multirow[t]{2}{*}{ Seniority } & $-0.097^{*}$ & -0.037 & -0.055 & -0.022 \\
\hline & $(0.051)$ & $(0.044)$ & $(0.051)$ & $(0.048)$ \\
\hline \multirow[t]{2}{*}{ Voter turnout } & & & $0.834^{* *}$ & $0.510^{*}$ \\
\hline & & & $(0.392)$ & $(0.287)$ \\
\hline \multirow[t]{2}{*}{ Share MPs Art. 29} & & & 0.094 & 0.014 \\
\hline & & & $(0.107)$ & $(0.096)$ \\
\hline \multirow[t]{2}{*}{ GDP per capita } & & $0.476^{*}$ & & $0.588^{* *}$ \\
\hline & & $(0.254)$ & & $(0.247)$ \\
\hline \multirow[t]{2}{*}{ Population density } & & $-0.035^{* * *}$ & & $-0.039 * * *$ \\
\hline & & $(0.007)$ & & $(0.009)$ \\
\hline \multirow[t]{2}{*}{ Literacy rates (lagged) } & & $0.035^{* *}$ & & $0.029^{* *}$ \\
\hline & & $(0.012)$ & & $(0.010)$ \\
\hline \multirow[t]{2}{*}{ School-age children over total pop. } & & 1.313 & & 1.095 \\
\hline & & $(1.273)$ & & $(1.326)$ \\
\hline \multirow[t]{2}{*}{ Older people over total pop. } & & 4.118 & & 2.504 \\
\hline & & $(3.066)$ & & $(4.595)$ \\
\hline Province FE & YES & YES & YES & YES \\
\hline Year FE & YES & YES & YES & YES \\
\hline Observations & 945 & 945 & 617 & 617 \\
\hline R-squared & 0.653 & 0.753 & 0.754 & 0.814 \\
\hline
\end{tabular}

Note: The lack of data on voter turnout reduces the number of observations in regressions (3) and (4). All regressions include a constant. Clustered robust standard errors in parentheses.

*** $\mathrm{p}<0.01,{ }^{* *} \mathrm{p}<0.05{ }^{*} \mathrm{p}<0.1$

The seniority of legislators shows a negative impact, but it is no longer significant once the control variables are included. Similarly, the share of dynastic opposition seats did not exert any statistically significant influence. Regarding the covariates, the results show that schooling investments were higher in richer, more literate provinces, as there is a positive and statistically significant effect of GDP per capita and lagged literacy rates. There was also a negative relationship between education expenditure and population density. This seems to confirm the claim of Pérez Moreda (1997) that schooling provision was higher in areas where small towns were predominant because of the way the Moyano Law was designed, since it required that at least one school be created in small towns. The rest of the demographic controls were not statistically significant.

Column 3 includes voter turnout and the share of MPs elected through Article 29. The latter did not affect schooling investments, while voter turnout showed a positive and statistically significant effect. The share of minority MPs and propios held their influence. The results remained unchanged in column 4 when the controls were included. In terms of magnitudes, the impact of political variables in column 4 implies that a rise of one standard deviation in the share of minority MPs and propios would produce a $12 \%$ and $13 \%$ decrease in the standard deviation of schooling expenditure, respectively, a substantial variation. This translates to a total reduction of 0.21 pesetas per capita. The positive effect of voter turnout 
did not countervail this negative impact, as it implied a 5\% increase in the standard deviation of the dependent variable (equivalent to 0.04 pesetas).

In Table 4, we tested whether a rise in the opposition made the government change its education investment strategy for the sake of political stability. Columns 1 and 2 allowed the impact of the share of minority and dynastic opposition MPs to change with the square of those variables with and without control variables, respectively. The estimates show that the increasing presence of minority parties did not change their negative effect on schooling expenditure (the square term is positive but not statistically significant). However, in the case of the dynastic opposition, the squared term turned positive and both coefficients were statistically significant.

The estimates in columns 3 and 4 replicate the two previous computations, but now include voter turnout and the share of MPs elected under Article 29. The impact of political participation was again positive and significant. However, once we controlled for it, the positive influence of the share of dynastic opposition MPs was no longer significant, thus suggesting that it had perhaps captured part of the effect of voter turnout. In turn, in these specifications, the increasing presence of minority MPs maintained its positive sign, but this time it was also statistically significant. According to column 4, the net impact of minorities starts to be positive when they occupy more than $65 \%$ of the seats at the provincial level. This might reflect the fact that the government's strategy of punishing constituencies that voted for minority parties prevailed over its attraction strategy until the share of minority MPs achieved a high threshold. The share of propios kept the same sign and influence shown in Table 3. 
Table 4. Impact of a rise in the opposition on primary education expenditure

\begin{tabular}{|c|c|c|c|c|}
\hline \multirow[t]{2}{*}{ Dependent variable } & \multicolumn{4}{|c|}{ Primary education exp. per capita (constant pesetas) } \\
\hline & $(1)$ & $(2)$ & (3) & $(4)$ \\
\hline \multirow[t]{2}{*}{ Share minority seats } & $-0.825^{* *}$ & $-0.693^{* *}$ & $-1.015^{* *}$ & $-1.007^{* * *}$ \\
\hline & $(0.362)$ & $(0.298)$ & $(0.401)$ & $(0.340)$ \\
\hline \multirow[t]{2}{*}{ Share minority seats squared } & 0.395 & 0.307 & $0.673^{*}$ & $0.752^{* *}$ \\
\hline & $(0.335)$ & $(0.280)$ & $(0.377)$ & (0.321) \\
\hline \multirow[t]{2}{*}{ Share dynastic opposition seats } & $-0.590^{* *}$ & $-0.555^{*}$ & -0.569 & -0.459 \\
\hline & $(0.274)$ & $(0.253)$ & $(0.352)$ & $(0.331)$ \\
\hline \multirow{2}{*}{ Share Dynastic opp. seats squared } & $0.820^{* *}$ & $0.783^{*}$ & 0.795 & 0.648 \\
\hline & $(0.377)$ & $(0.352)$ & $(0.517)$ & $(0.486)$ \\
\hline \multirow[t]{2}{*}{ Share propios } & $-0.485^{* * *}$ & $-0.324^{* * *}$ & $-0.619 * * *$ & $-0.487^{* * *}$ \\
\hline & $(0.130)$ & $(0.101)$ & $(0.174)$ & $(0.133)$ \\
\hline \multirow[t]{2}{*}{ Voter turnout } & & & $0.791^{* *}$ & $0.484^{*}$ \\
\hline & & & $(0.373)$ & $(0.269)$ \\
\hline \multirow[t]{2}{*}{ Seniority } & $-0.097^{*}$ & -0.041 & -0.060 & -0.029 \\
\hline & $(0.051)$ & $(0.044)$ & $(0.051)$ & $(0.048)$ \\
\hline \multirow[t]{2}{*}{ Share MPs Art. 29} & & & 0.062 & -0.019 \\
\hline & & & $(0.108)$ & $(0.098)$ \\
\hline \multirow[t]{2}{*}{ GDP per capita } & & $0.530^{* *}$ & & $0.665^{* * *}$ \\
\hline & & $(0.256)$ & & $(0.245)$ \\
\hline \multirow{2}{*}{ Population density } & & $-0.035^{* * *}$ & & $-0.037^{* * *}$ \\
\hline & & $(0.007)$ & & $(0.008)$ \\
\hline \multirow[t]{2}{*}{ Literacy rates (lagged) } & & $0.033^{* *}$ & & $0.029^{* *}$ \\
\hline & & $(0.012)$ & & (0.011) \\
\hline \multirow[t]{2}{*}{ School-age children over total pop. } & & 1.839 & & 1.294 \\
\hline & & (1.251) & & (1.349) \\
\hline \multirow[t]{2}{*}{ Elderly people over total pop. } & & 4.154 & & 2.630 \\
\hline & & (2.913) & & $(4.457)$ \\
\hline Province FE & YES & YES & YES & YES \\
\hline Year FE & YES & YES & YES & YES \\
\hline Observations & 945 & 945 & 617 & 617 \\
\hline R-squared & 0.660 & 0.758 & 0.760 & 0.820 \\
\hline
\end{tabular}

Note: All regressions include a constant. Clustered robust standard errors in parentheses.

${ }^{* * *} \mathrm{p}<0.01,{ }^{* *} \mathrm{p}<0.05,{ }^{*} \mathrm{p}<0.1$

As shown in Section 3, minority parties tended to grow more in urbanized and industrialized areas. This is because elections became increasingly competitive in industrial cities after the introduction of universal male suffrage in 1890. Therefore, the traditional political methods that were predominant in rural areas ended up coexisting with the modern political behavior seen in industrial cities (Moreno-Luzón, 2007). One might argue that the change in government strategy towards minority parties observed in the previous estimations could, in fact, be the result of an urban-rural effect, given the more competitive nature of elections in less rural contexts, instead of simply a response to the increasing threat from the opposition. To test this possibility, we introduced an interaction term between the share of MPs belonging to the opposition and the share of non-rural employment in each province in Table 5 to account for the differing nature of elections in less rural contexts.

Column 1 shows the results after the non-rural employment interaction was included. We added the share of opposition MPs squared into column 2. In columns 3 and 4, we also included an interaction term between the share of minority seats and dummy variables for Madrid and Barcelona. This accounted for the fact that these two provinces were 
disproportionately urbanized in the Spanish context, with non-rural employment rates above $60 \%$ from the beginning of the period, compared to the national average of $30 \%$. Finally, column 4 reports the results after the rest of the political variables in our model were interacted with the share of non-rural employment. Regression results show that there was indeed a non-rural effect. The interaction term between the share of minority parties and the share of non-rural employment was positive and statistically significant in all estimates. The same interaction with the share of dynastic opposition seats rendered no significant effects. As for the share of minority parties MPs squared, this also remained positive, although it was statistically significant only in columns 3 and 4 . Therefore, the regression results suggest that the increasing political representation of minority parties translated into increasing education spending, but that this effect was more pronounced in less rural areas. In other words, it seems that the government's strategy of punishing constituencies that voted for minority parties gradually turned into an attraction strategy as the electoral representation of minority parties and urbanization increased. 
Table 5. Non-rural provinces and political determinants of primary education expenditure

\begin{tabular}{|c|c|c|c|c|}
\hline \multirow[t]{2}{*}{ Dependent variable } & \multicolumn{4}{|c|}{ Primary education exp. per capita (constant pesetas) } \\
\hline & $(1)$ & $(2)$ & (3) & (4) \\
\hline Share minority seats & $\begin{array}{c}-1.944^{* * *} \\
(0.621)\end{array}$ & $\begin{array}{c}-2.229^{* * *} \\
(0.489)\end{array}$ & $\begin{array}{c}-2.584^{* * *} \\
(0.659)\end{array}$ & $\begin{array}{c}-2.607^{* * *} \\
(0.744)\end{array}$ \\
\hline Share minority seats squared & & $\begin{array}{c}0.576 \\
(0.391)\end{array}$ & $\begin{array}{c}0.741^{*} \\
(0.391)\end{array}$ & $\begin{array}{c}0.702^{*} \\
(0.417)\end{array}$ \\
\hline Share min. seats $x$ sh. non-rural emp. & $\begin{array}{c}4.481^{* * *} \\
(1.568)\end{array}$ & $\begin{array}{c}4.169 * * * \\
(1.351)\end{array}$ & $\begin{array}{c}5.162^{* * *} \\
(1.896)\end{array}$ & $\begin{array}{l}5.317^{* *} \\
(2.175)\end{array}$ \\
\hline Share dynastic opp. seats & $\begin{array}{c}-0.150 \\
(0.279)\end{array}$ & $\begin{array}{c}-0.600 \\
(0.395)\end{array}$ & $\begin{array}{c}-0.600 \\
(0.398)\end{array}$ & $\begin{array}{c}-0.630 \\
(0.380)\end{array}$ \\
\hline Share dynastic opp. seats squared & & $\begin{array}{c}0.643 \\
(0.490)\end{array}$ & $\begin{array}{c}0.629 \\
(0.494)\end{array}$ & $\begin{array}{c}0.671 \\
(0.485)\end{array}$ \\
\hline Share dyn. seats $x$ sh. non-rural emp. & $\begin{array}{c}0.551 \\
(0.872)\end{array}$ & $\begin{array}{c}0.566 \\
(0.892)\end{array}$ & $\begin{array}{c}0.609 \\
(0.877)\end{array}$ & $\begin{array}{c}0.650 \\
(0.837)\end{array}$ \\
\hline Share propios & $\begin{array}{c}-0.440^{* * *} \\
(0.141)\end{array}$ & $\begin{array}{c}-0.479 * * * \\
(0.140)\end{array}$ & $\begin{array}{c}-0.488^{* * *} \\
(0.140)\end{array}$ & $\begin{array}{c}-0.563^{* *} \\
(0.251)\end{array}$ \\
\hline Share propios $\mathrm{x}$ sh. non-rural emp. & & & & $\begin{array}{c}0.449 \\
(0.817)\end{array}$ \\
\hline Voter turnout & $\begin{array}{c}0.428^{*} \\
(0.255)\end{array}$ & $\begin{array}{c}0.411^{*} \\
(0.241)\end{array}$ & $\begin{array}{c}0.433 \\
(0.258)\end{array}$ & $\begin{array}{c}0.119 \\
(0.573)\end{array}$ \\
\hline Voter turnout x sh. non-rural emp. & & & & $\begin{array}{c}1.125 \\
(1.932)\end{array}$ \\
\hline Relative seniority & $\begin{array}{c}-0.017 \\
(0.046)\end{array}$ & $\begin{array}{c}-0.022 \\
(0.046)\end{array}$ & $\begin{array}{c}-0.024 \\
(0.045)\end{array}$ & $\begin{array}{c}0.020 \\
(0.061)\end{array}$ \\
\hline Relative seniority x sh. non-rural emp. & & & & $\begin{array}{c}-0.133 \\
(0.116)\end{array}$ \\
\hline Share MPs Art. 29 & $\begin{array}{c}-0.002 \\
(0.099)\end{array}$ & $\begin{array}{l}-0.027 \\
(0.102)\end{array}$ & $\begin{array}{c}-0.029 \\
(0.102)\end{array}$ & $\begin{array}{c}-0.043 \\
(0.100)\end{array}$ \\
\hline Share non-rural employment & $\begin{array}{c}0.163 \\
(1.310)\end{array}$ & $\begin{array}{c}0.129 \\
(1.270)\end{array}$ & $\begin{array}{c}0.107 \\
(1.284)\end{array}$ & $\begin{array}{c}-0.231 \\
(1.910)\end{array}$ \\
\hline GDP per capita & $\begin{array}{c}0.278 \\
(0.242)\end{array}$ & $\begin{array}{c}0.367 \\
(0.248)\end{array}$ & $\begin{array}{c}0.228 \\
(0.312)\end{array}$ & $\begin{array}{c}0.211 \\
(0.300)\end{array}$ \\
\hline Population density & $\begin{array}{c}-0.054^{* * *} \\
(0.012)\end{array}$ & $\begin{array}{c}-0.052^{* * *} \\
(0.011)\end{array}$ & $\begin{array}{c}-0.055^{* * *} \\
(0.013)\end{array}$ & $\begin{array}{c}-0.044^{* * *} \\
(0.015)\end{array}$ \\
\hline Literacy rates (-10 lagged) & $\begin{array}{c}0.030^{* * *} \\
(0.010)\end{array}$ & $\begin{array}{c}0.029 * * * \\
(0.010)\end{array}$ & $\begin{array}{c}0.029 * * * \\
(0.010)\end{array}$ & $\begin{array}{l}0.027^{* *} \\
(0.010)\end{array}$ \\
\hline School-age children over total pop. & $\begin{array}{c}1.137 \\
(1.419)\end{array}$ & $\begin{array}{c}1.324 \\
(1.418)\end{array}$ & $\begin{array}{c}1.432 \\
(1.414)\end{array}$ & $\begin{array}{c}1.084 \\
(1.531)\end{array}$ \\
\hline Elderly people over total pop. & $\begin{array}{c}2.522 \\
(4.346)\end{array}$ & $\begin{array}{c}2.580 \\
(4.257)\end{array}$ & $\begin{array}{c}2.600 \\
(4.190)\end{array}$ & $\begin{array}{c}3.633 \\
(4.353)\end{array}$ \\
\hline Province FE & YES & YES & YES & YES \\
\hline Year FE & YES & YES & YES & YES \\
\hline Observations & 617 & 617 & 617 & 617 \\
\hline R-squared & 0.823 & 0.827 & 0.828 & 0.831 \\
\hline
\end{tabular}

Note: All regressions include a constant. Clustered robust standard errors in parentheses. Columns 3 and 4 include interaction dummies for the share of minority seats and Madrid and Barcelona (not included for the sake of brevity).

${ }^{* * *} \mathrm{p}<0.01,{ }^{* *} \mathrm{p}<0.05,{ }^{*} \mathrm{p}<0.1$

As mentioned above, elections in more urbanized areas became increasingly competitive. The government lost its power to manipulate electoral results, particularly in big cities, and mass parties and modern political behavior gained ground at the expense of clientelist methods. It seems that it was in this context that the government decided to increase 
education spending - i.e., a public good targeted at large segments of the population, presumably with high demand in urban areas - in search of electoral support. Conversely, in more rural areas, where the demand for education was probably lower and traditional political methods remained more effective, a given share of minority party MPs must have been less threatening to the government. However, it is important to note that the marginal effect of the share of minority party seats based on the estimations in column 3 (Table 5) is positive when the share of non-rural employment is above $49 \%$ (if we use the estimates in columns 1 and 2, this threshold is $45 \%$ and $52 \%$, respectively). This condition was fulfilled only in Barcelona and Madrid, and then the Baleares Islands, Cadiz, Santander and Seville for a few years at the end of our time period. This again suggests that the punishment strategy was predominant.

As for the share of propios, it is worth noting that this variable retained its negative and statistically significant effect across all estimates, even in column 4, when it was interacted with the share of non-rural employment. This suggests that propios did not have any incentive to struggle for education resources that would benefit both clients and nonclients, regardless of the prevailing economic activities at the provincial level. In the case of voter turnout, the results show that this tended to be positive, but was no longer statistically significant when interacted with the share of non-rural employment.

Finally, a note on the robustness of the results: one possible concern relates to the potential presence of spatial correlation or cross-sectional dependence among provinces. Unobserved common factors captured in the disturbance term and not correlated with the regressors might make the fixed effects estimators consistent but would not make the efficient and standard errors biased (Pesaran, 2004; Baltagi, 2005). We tested for the presence of spatial correlation, but found no evidence in this regard (see Table A.1 in the appendix). Additionally, in Table A.2, we controlled for possible heteroskedasticity and serial autocorrelation in the disturbance term. In Table A.3, we replicated our estimates with an alternative definition of schooling outlays (primary education expenditure per school-age child). In all cases, the main results held.

\section{Conclusions}

Just after the turn of the 20th century, Spanish policymakers devised an education reform to promote schooling expansion. Education was centralized in 1902 and the government took over the payment of primary school teachers' salaries and the purchase of school supplies. Nation-building motivations undoubtedly explain the timing of this reform. It was introduced shortly after the resounding military defeat by the US and the loss of the last colonies in Cuba and the Philippines. However, the implementation of the reform was hindered by the political dynamics of Restoration Spain. To explore this subject further, we examined the allocation of government spending on primary education across Spanish provinces in 1902-1922, when the reform was implemented.

Regression results show that education spending was negatively correlated with the share of MPs belonging to minority parties. However, this relationship was non-linear and turned positive for higher levels of minority party representation. The results also show that the government was more responsive to minority opposition representation in more industrial provinces, where elections were actually more competitive. This suggests that the lack of 
effective political competition initially enabled the government to ignore voter demands in less loyal constituencies, which is consistent with the behavior expected of a semidemocratic regime. However, as opposition increased, especially when this growth was concentrated in industrial cities, the government replaced its initial punishment strategy with one of attraction. Nonetheless, this positive effect occurred only in some specific provinces, with particularly high levels of minority party representation and non-rural employment, which would suggest that the punishment strategy predominated across provinces and over time.

The share of propios (candidates with particularly strong clientelist ties to local elites) also shows a negative and statistically significant effect. This means that primary education outlays were smaller in provinces where political patronage was more widespread. Arguably, propios had little incentive to provide a non-targeted good, such as primary education, which would have benefited both their clients and non-clients. Finally, even despite the corruption, we found that voter turnout had a positive effect on primary education spending. The ruling elite were not completely immune to demands from below. However, this effect was not big enough to compensate for the negative impact of the lack of effective electoral competition and widespread political patronage. The 1902 reform, which centralized primary education, was not the direct result of pressures from below, but the political dynamics and democratic shortcomings of Restoration Spain limited its potential positive effects. 


\section{References}

Andersson, J. and Berger, T. 2018. Elites and the expansion of education in nineteenthcentury Sweden. The Economic History Review 72(3): 897-924.

Azar, P. (forthcoming) Politics as a determinant of primary school provision. The case of Uruguay. Cliometrica.

Baltagi, B. H. 2005. Econometric Analysis of Panel Data. 3rd ed. New York: Wiley.

Beltran Tapia, F. 2013. Enclosing literacy? Common lands and human capital in Spain, 18601930. Journal of Institutional Economics 9(4): 491-515.

Beltrán-Tapia, F., Díez-Minguela, A., Martínez-Galarraga, J. y Tirado-Fabregat, D. 2019. Capital humano y desigualdad territorial. El proceso de alfabetización en los municipios españoles desde la Ley Moyano hasta la Guerra Civil. Estudios de Historia Económica № 74. Madrid: Banco de España.

Beltrán Tapia, F. and Martínez- Galarraga, J. 2018. Inequality and education in pre-industrial economies: evidence from Spain. Explorations in Economic History, 69, 81-101.

Cappelli, G. 2016a. One size that didn't fit all? Electoral franchise, fiscal capacity and the rise of mass schooling across Italy's provinces, 1870-1911. Cliometrica 10(3): 311-343.

Cappelli, G. 2016b. Escaping from a human capital trap? Italy's regions and the move to centralized primary schooling, 1861 - 1936. The European Review of Economic History 20(1): 46-65.

Cappelli, G. and Vasta, M. 2020. Can school centralization foster human capital accumulation? A quasi-experiment from early twentieth-century Italy. The Economic History Review 73(1): 159-184.

Chaudhary, L.; Musacchio, A.; Nafziger, S.; and Yan, S. 2012. Big BRICs, weak foundations: The beginning of public elementary education in Brazil, Russia, India, and China. Explorations in Economic History, 49, 221-240

Cinnirella, F and Schueler, R. 2018. Nation building: The role of central spending in education, Explorations in Economic History, 67: 18-39.

Cinnirella, F. and Hornung, E. 2016. Landownership concentration and the expansion of education. Journal of Development Economics, 121, 135-152.

Comín, F. 1988. Hacienda y economía en la España contemporánea (1800-1936). Madrid: Instituto de Estudios Fiscales.

Cox, G. 2010. Swing voters, core voters, and distributive politics. In Shapiro, I., Stokes, S., Wood, E. and Kirshner, A. (eds.), Political Representation. Cambridge: Cambridge University Press.

Cox, G. and McCubbins, M. 1986. Electoral Politics as a redistributive game. Journal of Politics 48(2), 370-89. 
Crafts, N.F.R. 1997. The Human Development Index and changes in standards of living: Some historical comparisons, European Review of Economic History, 1, 299-322.

Curto, M., Herranz, A. and Solé, A. 2012. Pork-Barrel Politics in Semi-Democracies: The Spanish "Parliamentary Roads" 1880-1914. The Journal of Economic History 72(3), 771-796.

Cvrcek, T. and Zajicek, M. 2019. The rise of public schooling in nineteenth- century Imperial Austria: Who gained and who paid? Cliometrica 13(3): 367-403.

Díez-Minguela A, Martinez-Galarraga J, Tirado Fabregat D. 2016. Why did Spanish regions not converge before the Civil War? Agglomeration and (regional) growth revisited. Revista de Historia Económica - Journal of Iberian and Latin American Economic History 34(3): 417448.

Dixit, A. and Londregan, J. 1998. Ideology, tactics, and efficiency in redistributive politics. The Quarterly Journal of Economics 113,497-529.

Eli, S. and Salisbury, L. 2016. Patronage politics and the development of the welfare state: Confederate Pensions in the American South. The Journal of Economic History 76(4): 10781112.

Engerman, S. L., Mariscal, E. and Sokolo, K. L. 2009. The Evolution of Schooling in the Americas, 1800-1925. In Eltis, D., Lewis, F. and Sokolof, K. (eds) Human Capital and Institutions: A Long-Run View. Cambridge: Cambridge University Press.

Galor, O., Moav, O. and Vollrath, D. 2009. Inequality in landownership, the emergence of human-capital promoting institutions and the Great Divergence, Review of Economic Studies 76(1), 143-179.

Go, S. and Lindert, P. 2010. The Uneven Rise of American Public Schools to 1850. Journal of Economic History 70, 1-26.

Golden, M. and Min, B. 2013. Distributive politics around the world. Annual Review of Political Sciences 16, 73-99.

Goldin, C. and Katz, L. 2008. The Race between Education and Technology. Cambridge, MA: Harvard University Press.

Goñi, M. 2018. "Landed Elites and Education Provision in England: Evidence from School Boards, 1871-99”, unpublished manuscript.

Green, A. 1990. Education and State Formation: The Rise of Education Systems in England, France and the USA. New York: St. Martin's Press.

Keefer, P. 2007. Clientelism, Credibility, and the Policy Choices of Young Democracies. American Journal of Political Science, 51(4): 804-821

Keefer, P. and Khemani, S. 2005. Democracy, public expenditure and the poor: understanding political incentives for providing public services. The World Bank Research Observer, 20(1): 1-27. 
Lindbeck, A. and Weibull, J. 1987. Balanced budget redistribution and the outcome of political competition. Public Choice 52: 273-97.

Lindert, P. 2004. Growing public: social spending and economic growth since the eighteenth century. Cambridge: Cambridge University Press.

Mariscal, E. and Sokoloff, K. 2000. Schooling, Suffrage and the Persistence of Inequality in the Americas. In Haber, S. (ed) Political Institutions and Economic Growth in Latin America: Essays in Policy, History and Political Economy, 159- 218. Stanford, California: Hoover Institution Press.

Martínez Cuadrado, M. 1969. Elecciones y partidos políticos de España: 1868-1931. Madrid: Taurus.

Melton, J. VH. 1988. Absolutism and the Eighteenth-Century Origins of Compulsory Schooling in Prussia and Austria. Cambridge, UK: Cambridge University Press.

Moreno Luzón, J. 2001. Los liberals y la educación hace cien años: Romanones en el Ministerio. In Álvarez Lázaro, P. (dir.) Cien años de educación en España. Fundación BBVA, Ministerio de Educación, Cultura y Deporte: 201-221

Moreno-Luzón, J. 2007. Political Clientelism, Elites and Caciquismo in Restoration Spain (1875_1923). European History Quarterly 37(3): 417-441.

Núñez, C. E. 1992. La fuente de la riqueza. Educación y desarrollo económico en la España contemporánea. Madrid: Alianza Editorial.

1991. El gasto público en educación entre 1860 y 1935. Hacienda Pública

Española, 1: 121-146.

O'Rourke, K. and Williamson, J.G. 1997. Around the European Periphery, 1870-1913: Globalisation, Schooling and Growth. European Review of Economic History, 1: 153- 190.

Otero Carvajal, L. 2018. La educación en España. La apuesta por la Modernidad. Reducción del analfabetismo y participación de las mujeres en el sistema educativo, 1900-1936. En Otero Carvajal, L. and de Miguel Salanova, S. (eds) La escuela y la despensa. Indicadores de Modernidad. España, 1900-1936: 17-51. Madrid: Catarata.

Paglayan, A. 2020. The non-democratic roots of mass education: evidence from 200 years. American Political Science Review, 1-20.

Pardo Bazán, E., “Informes o testimonios”, en Costa, J. (1982[1901]), Oligarquía y caciquismo como la forma actual de gobierno en España: urgencia y modo de cambiarla. Zaragoza: Guara.

Pérez Moreda, V. 1997. El proceso de alfabetización y la formación de capital humano en España. Papeles de Economía Española, 73: 243-253. 
Pesaran, M. H. 2004. General diagnostic tests for cross section dependence in panels. Working Papers in Economics No. 0435 Faculty of Economics, University of Cambridge.

Prados de la Escosura, L. and Rosés, J.R. 2010. Human capital and economic growth in Spain, 1850-2000. Explorations in Economic History, 47, 520-532.

Ramirez, F.O. and Boli, J. 1987. The Political Construction of Mass Schooling: European Origins and Worldwide Institutionalization. Sociology of Education 60(1): 2-17.

Robinson, R. and Torvik, R. 2009. A political economy theory of the soft budget constraint. European Economic Review 53(7): 786-798.

Rosés J, Martinez-Galarraga J, Tirado D. 2010. The upswing of regional income inequality in Spain (1860-1930). Explorations in Economic History 47(2): 244-257.

Sabaté, O., Espuelas, S., and Herranz-Loncán, A. (forthcoming). Military wages and coups d'état in Spain (1850-1915): the use of public spending as a coup-proofing strategy, Revista de Historia Económica - Journal of Iberian and Latin American Economic History

Stokes, S.C. 2005. Perverse Accountability: A Formal Model of Machine Politics with Evidence from Argentina. American Political Science Review 99(3): 315-325.

Varela Ortega, J. (dir.). 2001. El poder de la influencia. Geografía del caciquismo en España (1875-1923). Madrid: Marcial Pons.

Villares, R. and Moreno Luzón, J. 2009. Restauración y Dictadura. In Fontana, R. and Villares, R. (dir), Historia de España. Vol. 7. Barcelona: Crítica-Marcial Pons. 


\section{Figures}

Map 1 Literacy rates in Spanish provinces (1900)

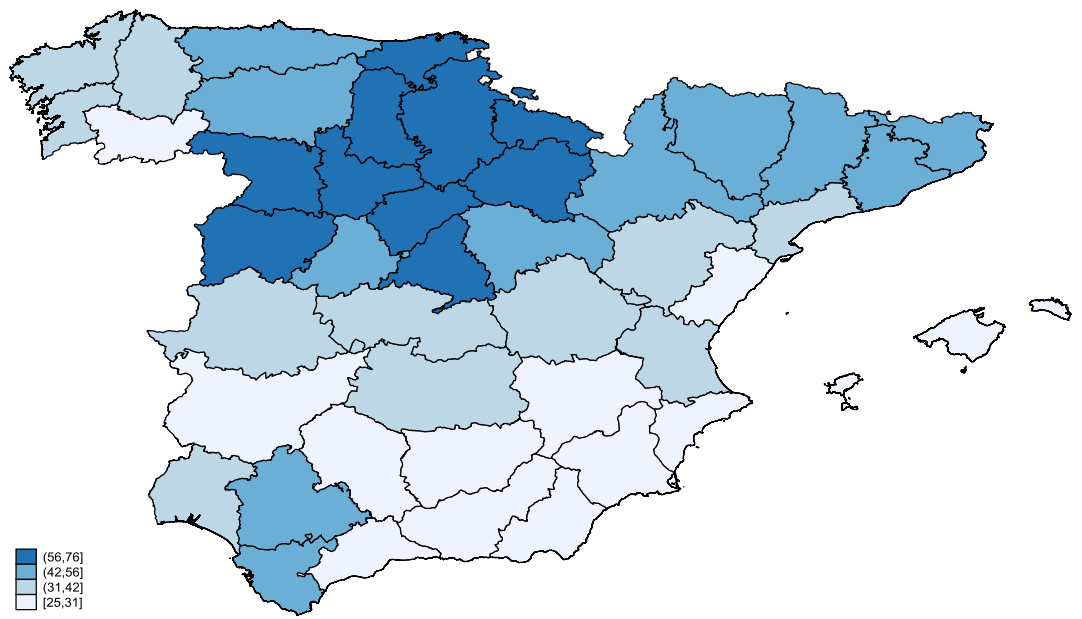

Source: Núñez (1992)

Map 2. Literacy rates in Spanish provinces (1920)

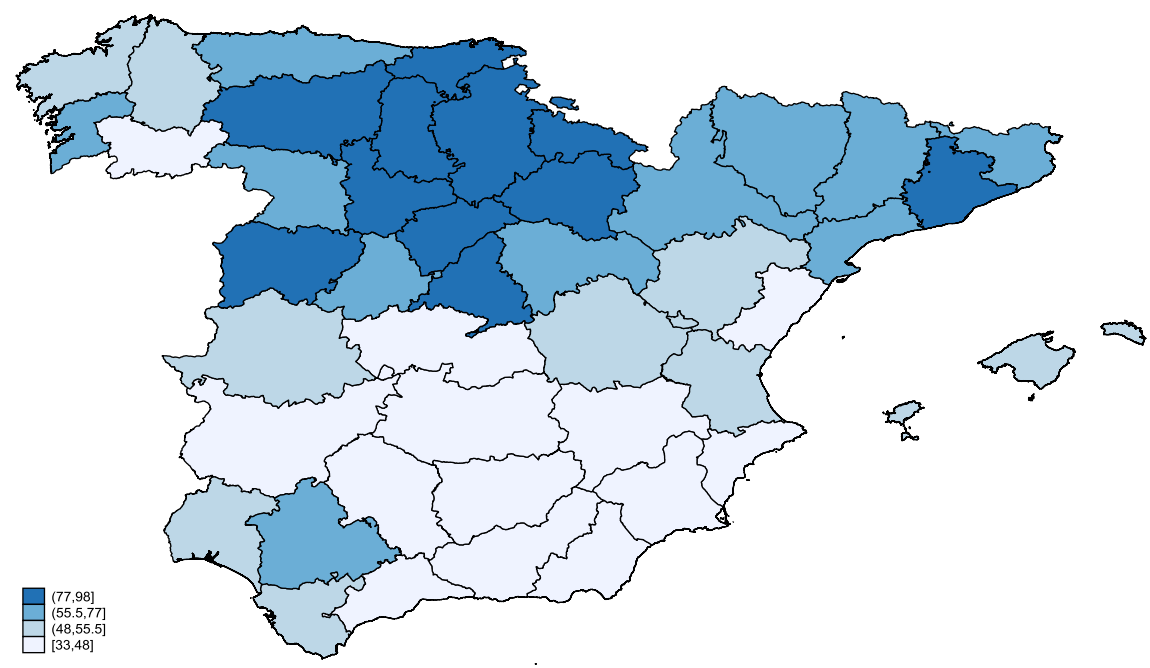

Source: Núñez (1992) 
Map 3. Central government expenditure per capita on primary education in Spain (19051920)
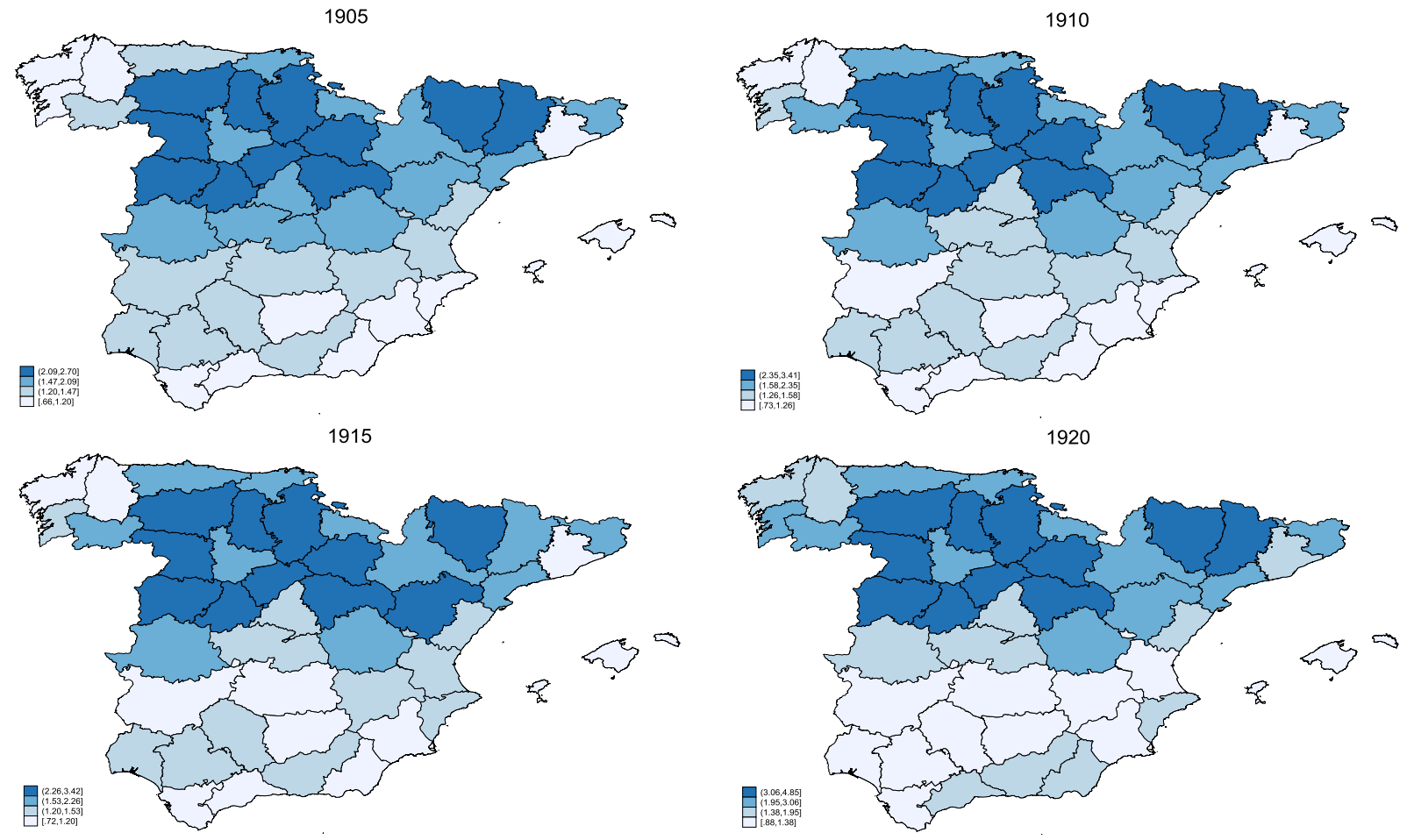

Source: See Section 4 for data sources and details

Figure 1. Share of minority and dynastic opposition parliamentary seats

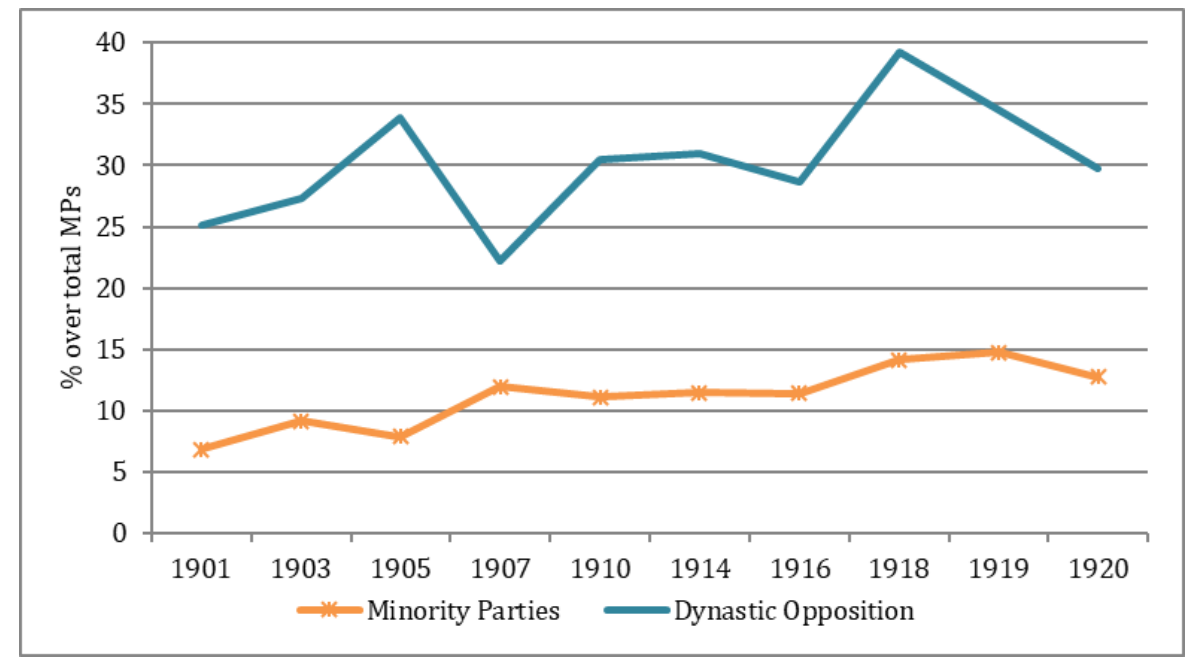

Source: See section 4.1 for data sources and details 


\section{Appendix}

Map A.1 Distribution of Propios MPs across Spanish provinces (1905 and 1920)

1905

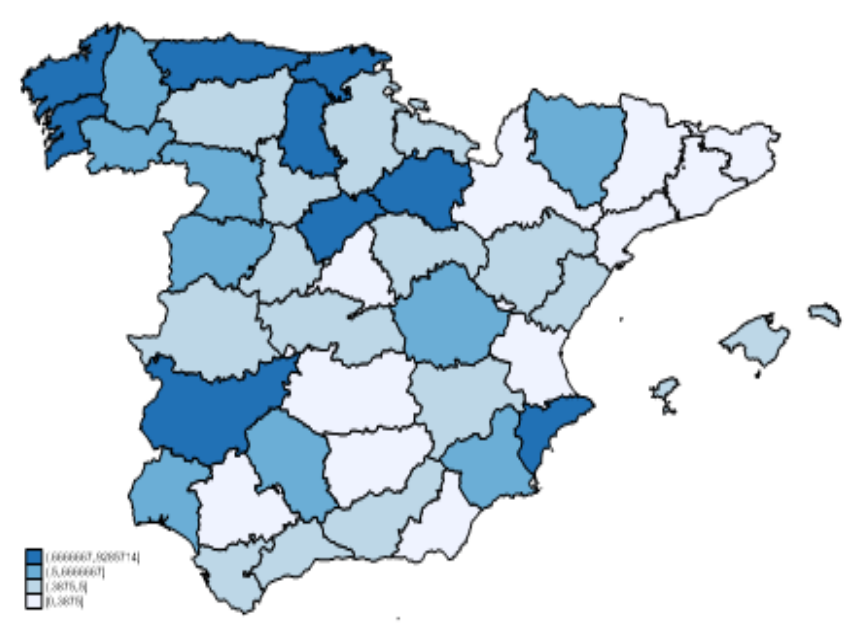

1920

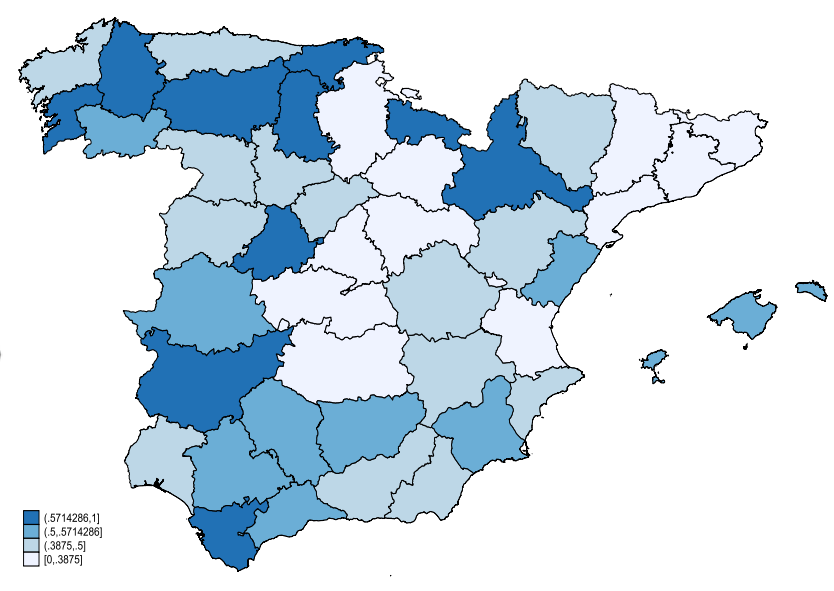


Table A.1 Pesaran's test for baseline results

\begin{tabular}{lccc}
\hline Baseline estimates & T. 3 Col. 4 & T. 4. Col. 4 & T. 5. Col. 2 \\
\hline \hline $\begin{array}{l}\text { Pesaran's test for cross-sectional } \\
\text { independence }\end{array}$ & -0.161 & -0.626 & -0.841 \\
$\begin{array}{l}\text { HO: cross-sectional independence } \\
\text { Prob. }\end{array}$ & 1.128 & 1.469 & 1.600 \\
\hline
\end{tabular}


Table A.2. Baseline heteroskedasticity and autocorrelation-consistent results

\begin{tabular}{|c|c|c|c|}
\hline \multirow[t]{2}{*}{ Dependent variable } & \multicolumn{3}{|c|}{ Primary education exp. per capita (constant pesetas) } \\
\hline & $(1)$ & (2) & (3) \\
\hline Share minority seats & $\begin{array}{c}-0.511^{* * *} \\
(0.160)\end{array}$ & $\begin{array}{c}-1.007^{* * *} \\
(0.299)\end{array}$ & $\begin{array}{c}-1.944^{* * *} \\
(0.443)\end{array}$ \\
\hline Share minority seats squared & & $\begin{array}{l}0.752^{* *} \\
(0.309)\end{array}$ & \\
\hline Share min. seats $\mathrm{x}$ sh. non-rural emp. & & & $\begin{array}{c}4.481^{* * *} \\
(1.165)\end{array}$ \\
\hline Share dynastic opposition seats & $\begin{array}{l}-0.007 \\
(0.090)\end{array}$ & $\begin{array}{l}-0.459^{*} \\
(0.239)\end{array}$ & $\begin{array}{l}-0.150 \\
(0.219)\end{array}$ \\
\hline Share dynastic opp. seats squared & & $\begin{array}{l}0.648^{* *} \\
(0.328)\end{array}$ & \\
\hline Share dyn. seats $x$ sh. non-rural emp. & & & $\begin{array}{c}0.551 \\
(0.708)\end{array}$ \\
\hline Share propios & $\begin{array}{c}-0.439 * * * \\
(0.115)\end{array}$ & $\begin{array}{c}-0.487^{* * *} \\
(0.113)\end{array}$ & $\begin{array}{c}-0.440^{* * *} \\
(0.116)\end{array}$ \\
\hline Voter turnout & $\begin{array}{l}0.510^{* *} \\
(0.234)\end{array}$ & $\begin{array}{l}0.484^{* *} \\
(0.223)\end{array}$ & $\begin{array}{l}0.428^{* *} \\
(0.217)\end{array}$ \\
\hline Share non-rural employment & & & $\begin{array}{c}0.163 \\
(0.826)\end{array}$ \\
\hline Seniority & $\begin{array}{l}-0.022 \\
(0.034)\end{array}$ & $\begin{array}{l}-0.029 \\
(0.033)\end{array}$ & $\begin{array}{c}-0.017 \\
(0.031)\end{array}$ \\
\hline Share MPs Art. 29 & $\begin{array}{c}0.014 \\
(0.082)\end{array}$ & $\begin{array}{c}-0.019 \\
(0.082)\end{array}$ & $\begin{array}{c}-0.002 \\
(0.083)\end{array}$ \\
\hline Controls & YES & YES & YES \\
\hline Province FE & YES & YES & YES \\
\hline Year FE & YES & YES & YES \\
\hline Observations & 617 & 617 & 617 \\
\hline
\end{tabular}

Note: Estimates consider Newey-West standard errors. All regressions include a constant and controls for GDP per capita, population density, literacy rates (lagged), school-age children and older people over total population. ${ }^{* * *} \mathrm{p}<0.01,{ }^{* *} \mathrm{p}<0.05,{ }^{*} \mathrm{p}<0.1$ 
Table A.3. Robustness checks. Alternative definition of primary education expenditure.

\begin{tabular}{|c|c|c|c|}
\hline \multirow[t]{2}{*}{ Dependent variable } & \multicolumn{3}{|c|}{ Primary education expenditure per school-age children } \\
\hline & (1) & (2) & (3) \\
\hline \multirow[t]{2}{*}{ Share minority seats } & $-2.029 * * *$ & $-4.003^{* * *}$ & $-7.801^{* * *}$ \\
\hline & $(0.708)$ & (1.337) & (2.439) \\
\hline \multirow[t]{2}{*}{ Share minority seats squared } & & $3.004^{* *}$ & \\
\hline & & (1.311) & \\
\hline \multirow[t]{2}{*}{ Share min. seats $\mathrm{x}$ sh. non-rural emp. } & & & $18.109 * * *$ \\
\hline & & & $(6.280)$ \\
\hline \multirow[t]{2}{*}{ Share dynastic opposition seats } & 0.058 & -1.668 & -0.601 \\
\hline & $(0.427)$ & $(1.414)$ & $(1.084)$ \\
\hline \multirow[t]{2}{*}{ Share dynastic opp. seats squared } & & 2.477 & \\
\hline & & $(1.995)$ & \\
\hline \multirow[t]{2}{*}{ Share dyn. seats $x$ sh. non-rural emp. } & & & 2.568 \\
\hline & & & $(3.601)$ \\
\hline \multirow[t]{2}{*}{ Share propios } & $-2.051^{* * *}$ & $-2.236^{* * *}$ & $-2.039 * * *$ \\
\hline & $(0.568)$ & $(0.560)$ & $(0.586)$ \\
\hline \multirow[t]{2}{*}{ Voter turnout } & 1.430 & 1.329 & 1.114 \\
\hline & $(1.291)$ & $(1.213)$ & $(1.171)$ \\
\hline \multirow[t]{2}{*}{ Share non-rural employment } & & & -0.013 \\
\hline & & & $(5.257)$ \\
\hline \multirow[t]{2}{*}{ Seniority } & -0.195 & -0.221 & -0.182 \\
\hline & $(0.192)$ & $(0.189)$ & $(0.179)$ \\
\hline \multirow{2}{*}{ Share MPs Art. 29} & 0.167 & 0.035 & 0.108 \\
\hline & $(0.402)$ & $(0.404)$ & $(0.406)$ \\
\hline Controls & YES & YES & YES \\
\hline Province FE & YES & YES & YES \\
\hline Year FE & YES & YES & YES \\
\hline Observations & 617 & 617 & 617 \\
\hline R-squared & 0.814 & 0.819 & 0.822 \\
\hline
\end{tabular}

Note: All regressions include a constant and controls for GDP per capita, population density, literacy rates (10 years lagged), school-age children and older people over total population. Column 2 includes interaction dummies for the share of minority seats and Madrid and Barcelona (not included for the sake of brevity). Clustered robust standard errors in parentheses. ${ }^{* * *}$ $\mathrm{p}<0.01,{ }^{* *} \mathrm{p}<0.05,{ }^{*} \mathrm{p}<0.1$ 